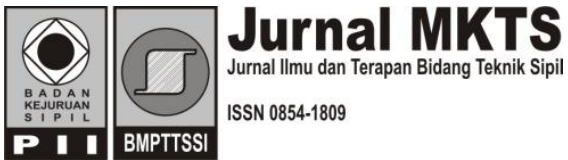

\title{
Evaluasi Keberhasilan Program Air Minum dan Sanitasi (PAMSIMAS) di Kabupaten Tegal dan Kabupaten Brebes
}

\author{
Abdul Kholiq \\ Program Studi Teknik Sipil, Fakultas Teknik, Universitas Majalengka \\ Jl. KH Abdul Halim No 103 Majalengka, Jawa Barat \\ E-mail: Choliq_fastac@yahoo.com
}

\begin{abstract}
Water supply and sanitationis one of the community-based program launched by the government to hel praise public awareness in water supply and sanitation trouble shooting. This study aims to evaluate the success of the service and performance of community-based water management through PAMSIMAS Program. Goals and objectives to be achieved in this research isto measure people's satisfaction PAMSIMAS program in the village of Karang Mulya and Jejeg in Tegal regency, and village Cilibur and Bentar in Brebes regency with performance assessment regulation of reference by Kepmendagri No.47, 1999 ${ }^{\text {th }}$. Factors community satisfaction was measured by an assessment of the ability of the management of water levels, namely: 1. Adequacy of water consumption, 2. Continuity of water, 3. Water quality, 4. Handling technical complaint sand 5. The attitude of the governing body of the society officers. Another goal is to do a SWOT analysis for the formulation of a strategic planin order to be sustainable PAMSIMAS Program infulfillment of clean water.
\end{abstract}

Keywords: Customer satisfaction, Performance managerial board of PAMSIMAS, PAMSIMAS program.

\begin{abstract}
Abstrak
Penyediaan air minum dan sanitasi berbasis masyarakat merupakan salah satu Program yang dilaksanakan pemerintah untuk membantu menumbuhkan kesadaran masyarakat dalam penyediaan air minum serta mengatasi masalah sanitasi. Penelitian ini bertujuan untuk melakukan evaluasi keberhasilan terhadap pelayanan dan kinerja pengelolaan air bersih berbasis masyarakat melalui Program PAMSIMAS. Tujuan dan sasaran yang ingin dicapai dalam penelitian ini yaitu mengukur kepuasan masyarakat terhadap Program PAMSIMAS di Desa Jejeg dan Desa Karang Mulya Kabupaten Tegal, serta Desa Cilibur dan Desa Bentar Kabupaten Brebes dengan acuan normatif penilaian kinerja PDAM berdasarkan Kepmendagri No.47 Tahun 1999. Faktor-faktor kepuasan masyarakat diukurberdasarkan penilaian atas kemampuan terhadap tingkat pengelolaan air bersih, yaitu: 1. kecukupan pemakaian air, 2. kontinuitas air, 3. kualitas air, 4. penanganan pengaduan teknis dan 5. sikap petugas badan pengelola terhadap masyarakat. Tujuan yang lain yaitu melakukan analisa SWOT untuk perumusan rencana strategis agar Program PAMSIMAS dapat berkesinambungan dalam pemenuhan akan air bersih.
\end{abstract}

Kata-kata Kunci: Kepuasan pelanggan, Kinerja badan pengelola PAMSIMAS, Program PAMSIMAS

\section{Pendahuluan}

Millenium Development Goals (MDGs) merupakan paradigma pembangunan global yang mempunyai delapan tujuan dengan delapan belas sasaran. Delapan tujuan tersebut adalah:

1. menanggulangi kemiskinan dan kelaparan,

2. mencapai pendidikan dasar untuk semua,

3. mendorong kesetaraan gender, dan pemberdayaan perempuan,
4. menurunkan angka kematian anak,

5. meningkatkan kesehatan ibu,

6. memerangi HIV/AIDs, malaria dan penyakit menulat lainnya,

7. memastikan kelestarian lingkungan hidup,

8. membangun kemitraan global untuk pembangunan. Penyediaan air bersih dan sanitasi merupakan bentuk dari tujuan yang ketujuh dari MDGs yaitu memastikan kelestarian lingkungan hidup. 
Pengelolaan sumber daya air bersih telah diatur dalam Undang-Undang Republik Indonesia No. 7 Tahun 2004 tentang Sumber Daya Air, namun kenyataannya tidak sedikit daerah yang sumber daya air masih belum mendapatkan perhatian yang cukup.

Program penyediaan air dan sanitasi berbasis masyarakat (PAMSIMAS) ini sangat diperlukan oleh masyarakat desa karena masyarakat dapat memperoleh air yang bersih yang dapat digunakan untuk minum, cuci, dan mandi. Permasalahan adalah bagaimana kinerja pelayanan dan pengelolaan air bersih melalui program penyediaan air minum dan Sanitasi berbasis masyarakat (PAMSIMAS) di Kabupaten Tegal dan Kabupaten Brebes?

Dalam kaitannya dengan Program PAMSIMAS tersebut peneliti bermaksud ingin melakukan penelitian terkait dengan pelayanan, penyediaan dan pengelolaan air bersih yang berbasis pada masyarakat di melalui Program PAMSIMAS di Desa Jejeg dan Desa Karang Mulya Kabupaten Tegal dan Desa Cilibur dan Desa Bentar Kabupaten Brebes.

Penelitian ini bertujuan untuk melakukan evaluasi keberhasilan pelayanan dan pengelolaan air bersih berbasis masyarakat melalui Program PAMSIMAS di Kabupaten Tegal dan Kabupaten Brebes, yaitu dengan:

a. Menganalisa kinerja pelayanan dan pengelolaan air bersih Badan Pengelola (BP) pada Program PAMSIMAS yang mengacu pada Kepmendagri No. 47 Tahun 1999 tentang kinerja pelayanan air bersih untuk PDAM.

b. Melakukan Analisa SWOT untuk perumusan rencana strategis agar Program PAMSIMAS dapat berkelanjutan dan berkesinambungan dalam pemenuhan akan air bersih.

\section{Tinjauan Pustaka}

\section{Program PAMSIMAS}

Berdasarkan laporan WHO-Unicef joint monitoring 2004 kinerja sektor Air Minum \& Sanitasi di Indonesia dinilai masih rendah dibandingkan dengan negara lain di Asia Tenggara. Diperkirakan penduduk Indonesia pada tahun 2015 adalah 218 juta jiwa, dimana 103 Juta jiwa atau $47 \%$ belum memiliki akses terhadap sanitasi dan 47 juta jiwa atau $22 \%$ belum memiliki akses terhadap air bersih. Angka yang lebih besar terlihat pada penduduk perdesaan, dimana diperkirakan $62 \%$ atau 73 Juta jiwa yang belum memiliki akses terhadap sanitasi dan $31 \%$ atau 36 juta jiwa yang tidak memiliki akses terhadap air bersih. Hanya
$50 \%$ dari seluruh penduduk Indonesia yang mendapatkan akses air minum (Susenas, 2002).

\section{Landasan hukum program PAMSIMAS}

Landasan hukum pelaksanaan Program Nasional Pelayanan Air Minum dan Sanitasi yang Berbasis Masyarakat adalah sebagai berikut: UU No. 7 Tahun 2004 tentang Sumber Daya Air, UU No. 32 Tahun 2004 tentang Pemerintahan Daerah, PP No. 16 Tahun 2005 tentang Pengembangan Sistem Penyediaan Air Minum, PP N0. 72 dan 73 Tahun 2005 tentang Pemerintahan Desa dan Pemerintahan Kelurahan, PP No. 7 Tahun 2004 tentang RPJMN Renstra 2004-2009 yaitu Pembangunan Prasarana dan Sarana Air Minum dan Sanitasi yang berkelanjutan dan Kebijakan Nasional Pembangunan Air Minum dan Penyehatan Lingkungan Berbasis Masyarakat, tahun 2003. Financing Agreement Financing Agreement Credit No 42040 IND.

\section{Tujuan umum Program PAMSIMAS}

Tujuan PAMSIMAS secara umum adalah meningkatkan akses pelayanan air minum dan sanitasi bagi masyarakat miskin perdesaan dan masyarakat urban, serta meningkatkan nilai dan perilaku hidup sehat dengan membangun/ menyediakan prasarana dan sarana air minum serta sanitasi berbasis masyarakat berkelanjutan dan mampu diadaptasi oleh masyarakat. Program ini akan menjadi model untuk direplikasi, diperluas (scaling up) dan pengarusutamaan (mainstreaming) model di daerah lain, dalam upaya mencapai target MDGs tahun 2015.

\section{Prinsip manajemen pengelolaan air bersih}

Dalam kegiatan layanan air bersih, perlu memperhatikan prinsip-prinsip manajemen, karena dalam menjalankan organisasi dibutuhkan manajemen pengelolaan. Manajemen/pengelolaan sumber daya air di definisikan sebagai aplikasi dari cara struktural dan non struktural untuk mengendalikan sistem sumber daya air alam dan buatan manusia untuk kepentingan/manfaat manusia dan tujuan-tujuan lingkungan (Grigg, 1996).

\section{Indikator kinerja pengelolaan jaringan (performance indicator)}

Indikator kinerja jaringan akan memfasilitasi terpenuhinya kebutuhan konsumen akan air bersih, serta akan memberikan masukan yang baik bagi pembangunan/pengembangan suatu sistem jaringan air bersih dari suatu kota/kawasan (Larry, 1999, Bab IX hal. 7). Sehingga dengan indikator kinerja jaringan yang baik, maka akan dapat memenuhi kebutuhan dan harapan pelanggan, 
sehingga dapat mencapai suatu tingkat kepuasan pelanggan. indikator kinerja meliputi (Larry, 1999, Bab IX hal.19): kepuasan pelanggan (customer satisfaction), kualitas (quality) dan tingkat ketersediaan (availability).

\section{Penilaian kinerja menurut Kepmendagri No. 47} tahun 1999

Penilaian kinerja PDAM menurut Kepmendagri No.47 tahun 1999 meliputi tiga aspek, yaitu aspek operasional, keuangan dan administrasi. Ketiga aspek tersebut memiliki indikator penilaian yaitu: Penilaian Kinerja Aspek Penilaian Kinerja Aspek Keuangan dan Penilaian Kinerja Aspek Administrasi.

\section{Metodologi Penelitian}

Pendekatan penelitian merupakan salah satu cara untuk mencapai tujuan dan sasaran penelitian. Berdasarkan tujuan dan sasaran yang ingin dicapai maka pendekatan penelitian yang akan dilakukan adalah kuantitatif deskriptif.

Tujuan tersebut menggambarkan bahwa penelitian ini mengkaji persepsi masyarakat secara mendalam, oleh karena itu pendekatan penelitian yang dilakukan ini didasarkan pada kondisi empirik yang ditemukan di lapangan. Operasional variable kepuasan masyarakat diukur berdasarkan penilaian responden atas kemampuan terhadap tingkat pengelolaan air bersih, yaitu sebagai berikut: kecukupan pemakaian air, kontinuitas air, kualitas air, Penanganan pengaduan teknis dan sikap petugas badan pengelola terhadap masyarakat.

Untuk mengetahui tingkat kepuasan masyarakat terhadap pelayanan air bersih didasarkan atas system penilaian dari skala likert. Pilihan jawaban berskor besar merupakan pilihan jawaban yang dianggap mempunyai tingkat kepuasan tertinggi. Nilai indikator tingkat kepuasan masyarakat sebagai pelanggan yaitu: 4-5 kepuasan sangat tinggi, 3-4 kepuasan tinggi, 2-3 kepuasan sedang, 1-2 kepuasan rendah, dan kurang dari 1 kepuasan sangat rendah. Untuk mengetahui kinerja pelayanan air bersih Program PAMSIMAS di Kabupaten Tegal dan Brebes, dilakukan pengukuran berdasarkan pada peraturan-peraturan yang berlaku dalam penilaian kinerja PDAM yaitu: Penilaian Kinerja PDAM berdasar Kepmendagri No.47 Tahun 1999, berdasarkan aspek operasional dan aspek administrasi.

Untuk mencari strategi pengembangan kapasitas pelayanan air bersih Program PAMSIMAS di Kabupaten Tegal dan Kabupaten Brebes digunakan analisis SWOT dengan cara menganalisis kekuatan, kelemahan, peluang dan ancaman pelayanan air bersih di Program PAMSIMAS. Analisis SWOT merupakan analisis kualitatif yang digunakan untuk mengidentifikasi kekuatan, kelemahan, peluang dan ancaman dalam pelayanan air bersih sehingga dapat dirumuskan/disusun strategi pengembangan kapasitas pelayanan.

\section{Hasil dan Pembahasan}

Penilaian kinerja pelayanan air bersih Program PAMSIMAS Kabupaten Brebes berdasarkan Kepmendagri No. 47 Tahun 1999

Dari lima aspek penilaian kinerja yang ditinjau berdasarkan aspek operasional, menunjukkan hasil penilaian yang beragam. Terdapat tiga aspek penilaian kinerja yang menunjukkan hasil penilaian baik, satu aspek penilaian kinerja menunjukkan hasil kurang baik. Sedangkan hasil penilaian sangat baik ditunjukkan dua aspek penilaian kinerja. Sehingga dapat disimpulkan bahwa dari aspek operasional kinerja badan pengelola Program PAMSIMAS dinilai Baik, dengan nilai 16 dari nilai maksimum 19. Sehingga disimpulkan dari aspek administrasi, Program PAMSIMAS di Kabupaten Brebes dinilai cukup baik, dengan nilai13 dari nilai maksimum 26.

Hasil penilaian akhir kinerja yang ditinjau dari kedua aspek penilaian diperoleh nilai akhir sebesar 64.43 berdasarkan Kepmendagri No. 47 Tahun1999 tentang Pedoman Penilaian Kinerja Pelayanan dan Pengelolaan Air Bersih (PDAM), nilai akhir tersebut berada pada nilai skor $>60-75$. Dengan hasil penilaian tersebut maka Program PAMSIMAS di Kabupaten Brebes (Desa Cilibur dan Desa Bentar berada dalam kategori baik, yang artinya baik memenuhi pada kinerja pelayanan yang diharapkan.

Tabel 1. Hasil penilaian akhir kinerja sesuai Kepmendagri No. 47 /1999. Program PAMSIMAS Kabupaten Brebes.

\begin{tabular}{|c|c|c|c|c|c|}
\hline No & Aspek kinerja & Nilai maksimal & Bobot (\%) & Niai kinerja & Nilai akhir \\
\hline $\mathrm{a}$ & $\mathrm{b}$ & $\mathrm{c}$ & $\mathrm{d}$ & $\mathrm{e}$ & $\mathrm{f}=(\mathrm{e} / \mathrm{c}) \mathrm{xd}$ \\
\hline 1 & Aspek operasional & 19 & 42,22 & 16 & 35,55 \\
\hline 2 & Aspek administrasi & 26 & 57,77 & 13 & 28,88 \\
\hline & Jumlah nilai akhir & & 100 & & 64,43 \\
\hline
\end{tabular}


Tabel 2. Hasil penilaian akhir kinerja sesuai Kepmendagri No. 47 /1999.

Program PAMSIMAS kabupaten tegal.

\begin{tabular}{cccccc}
\hline No & Aspek kinerja & $\begin{array}{c}\text { Nilai } \\
\text { Maks }\end{array}$ & Bobot (\%) & Nilai kinerja & Nilai akhir \\
\hline $\mathrm{a}$ & $\mathrm{b}$ & $\mathrm{c}$ & $\mathrm{d}$ & $\mathrm{e}$ & $\mathrm{f}=(\mathrm{e} / \mathrm{c}) \mathrm{xd}$ \\
\hline 1 & Aspek operasional & 19 & 42,22 & 15 & 33.33 \\
2 & Aspek administrasi & 26 & 57.77 & 14 & 31.11 \\
\hline \multicolumn{2}{r}{ Jumlah akhir nilai } & & 100 & & 64,44 \\
\hline Sumber: Hasil Analisis, 2013 & & &
\end{tabular}

Penilaian kinerja pelayanan air bersih Program PAMSIMAS Kabupaten Tegal berdasarkan Kepmendagri No. 47 tahun 1999

Terdapat tiga aspek penilaian kinerja yang menunjukkan hasil penilaian yang kurang baik, satu aspek penilaian kinerja menunjukkan hasil baik. Sedangkan hasil penilaian sangat baik ditunjukkan satu aspek penilaian kinerja. Sehingga dari seluruh hasil penilaian tersebut, dapat disimpulkan bahwa aspek operasional kinerja badan pengelola Program PAMSIMAS dinilai Baik, dengan nilai 15 dari nilai maksimum 19. Dan dari aspek administrasi, Program PAMSIMAS di Kabupaten Tegal dinilai cukup baik, dengan nilai 14 dari nilai maksimum 26.

Hasil penilaian akhir kinerja yang ditinjau dari kedua aspek penilaian diperoleh nilai akhir sebesar 64,44. Dengan hasil penilaian tersebut maka Program PAMSIMAS di Kabupaten Tegal berada dalam kategori baik, yang artinya baik untuk memenuhi pada kinerja pelayanan yang diharapkan.

\section{Analisis kondisi internal}

a. Kekuatan

- Adanya struktur organisasi, hasil analisis SWOT struktur organisasi sebagai kekuatan faktor internal memiliki bobot $24,14 \%$.

- Adanya rencana jangka panjang, Kekutan ini memiliki bobot $24,14 \%$ dalam menentukan keberhasilan Program PAMSIMAS.

- Rencana kerja, hasil analisis terhadapkondisiinternal Badan Pengelola dan LKM dalam merencanakan kegiatan dan anggaran termasuk kekuatan yang memiliki bobot $17,24 \%$.

- Tersedia prosedur operasi standar, hasil analisis SWOT tersedianya Prosedur Operasi Standar sebagai kekuatan faktor internal memiliki bobot terendah yaitu $13,79 \%$. b. Kelemahan

- Kualitas disribusi air, mengabaikan kualitas air bersih merupakan bagian dari faktor kelemahan internal Badan Pengelola. Urgensitas kelemahan ini mempunyai bobot faktor sebesar $6.90 \%$.

- Kontinuitas air, hasil analisa SWOT kontinuitas air merupakan faktor kelemahan dengan bobot 6,90\% apabila Badan Pengelola dan masyarakat mengabaikan hal tersebut.

- Kemampuan penanganan pengaduan, hasil analisa kondisi kemampuan penanganan pengaduan merupakan bagian dari kelemahan ini mempunyai bobot $3,45 \%$.

- Tingkat kemudahan pelayanan yang rendah, hasil analisa kondisi tingkat kemudahan dalam pelayanan pengaduan bagian dari kelemahan internal yang dimiliki badan pengelola. Faktor kelemahan ini memiliki bobot sebesar 3,45\% .

\section{Analisis kondisi eksternal}

a. Peluang

- Kegiatan pengelolaan air bersih pada saat Program PAMSIMAS ada menjadikan acuan dalam melakukan pelayanan air bersih. Hasil analisa SWOT adanya peraturan atau pedoman pelaksanaan Program PAMSIMAS memiliki bobot yaitu sebasar $15.38 \%$ sebagai peluang bagi BP dan LKM dalam pengelolaan air bersih.

- Lembaga Keswadayaan Masyarakat dan Badan Pengelola. Hasil analisa swot adanya koordinasi antar lembaga ini memiliki bobot $7.69 \%$ sebagai peluang dalam melayani kebutuhan air bersih masyarakat pada Program PAMSIMAS. 
Abdul Kholiq

Evaluasi Keberhasilan Program Air Minum dan Sanitasi (PAMSIMAS) di Kabupaten Tegal dan Kabupaten Brebes

Tabel 3. Matrik urgensi kondisi faktor internal

\begin{tabular}{|c|c|c|c|c|c|c|c|c|c|c|c|}
\hline \multirow{2}{*}{ No } & \multirow{2}{*}{ Uraian indikator } & \multicolumn{8}{|c|}{ Faktor yang lebih urgent } & \multirow{2}{*}{ Total } & \multirow{2}{*}{$\begin{array}{c}\text { Bobot } \\
\text { faktor }(\%)\end{array}$} \\
\hline & & 1 & 2 & 3 & 4 & 5 & 6 & 7 & 8 & & \\
\hline \multicolumn{12}{|c|}{ Kekuatan (strength) } \\
\hline 1 & $\begin{array}{l}\text { Adanya struktur organisasi LKM } \\
\text { sebagai badan pengelola }\end{array}$ & & 1 & 1 & 1 & 1 & 1 & 1 & 1 & 7 & $24.14 \%$ \\
\hline 2 & Ada rencana jangka panjang & 1 & & 2 & 2 & 2 & 2 & 2 & 2 & 7 & $24.14 \%$ \\
\hline 3 & Rencana kerja & 1 & 2 & & 3 & 3 & 3 & 3 & 3 & 5 & $17.24 \%$ \\
\hline 4 & Tersedia prosedur operasi standar & 1 & 2 & 3 & & 4 & 4 & 4 & 4 & 4 & $13.79 \%$ \\
\hline \multicolumn{12}{|c|}{ Kelemahan (weaknesses) } \\
\hline 5 & Kualitas disribusi air & 1 & 2 & 3 & 4 & & 6 & 5 & 5 & 2 & $6.90 \%$ \\
\hline 6 & Kontinuitas air belum 24 jam & 1 & 2 & 3 & 7 & 8 & & 6 & 6 & 2 & $6.90 \%$ \\
\hline 7 & Kemampuan penanganan pengaduan & 1 & 2 & 3 & 5 & 6 & 8 & & 7 & 1 & $3.45 \%$ \\
\hline 8 & $\begin{array}{l}\text { Tingkat kemudahan pelayanan } \\
\text { yang rendah }\end{array}$ & 1 & 2 & 3 & 5 & 6 & 7 & 8 & & 1 & $3.45 \%$ \\
\hline \multicolumn{10}{|c|}{ Jumlah } & 29 & $100.00 \%$ \\
\hline
\end{tabular}

- Untuk memenuhi kebutuhan masyarakat terhadap air bersih, pemerintah daerah terus berupaya menggalakkan sejumlah program salah satunya adalah penyediaan air Minum dan Sanitasi Berbasis lingkungan (Pamsimas). Hasil analisa Swot menempatkan Pemerintah Daerah dalam pengawasan program PAMSIMAS ini mempunyai bobot $5.13 \%$.

- Operasional pengelolaan yang dilakukan oleh badan pengelola merupakan pengembangan fungsi dari lembaga tersebut, masyarakat sebagai konsumen berfungsi mengawasi kegiatan operasional pengelolaan dan pelayanan air bersih Program PAMSIMAS. Peran pengawasan oleh masyarakat dalam analisa SWOT ini memlilki bobot $5.13 \%$.

b. Ancaman

- Di Desa Jejeg Kabupaten Tegal belum sepenuhnya melakukan penegakan hukum, bahkan tidak memberikan sanksi terdapat pelanggaran yang berat sekalipun. Dari hasil analisa SWOT terhadap Program PAMSIMAS kurangnya penguatan aspek penegakan hukum memiliki potensi ancaman sebesar $5.13 \%$ terhadap keberlanjutan Program PAMSIMAS.

- Kurang maksimalnya badan pengelola dalam menangani segala bentuk pengaduan masyarakat terhadap pelayanan air bersih yang menunjukan kurang optimalnya tanggung jawab badan pengelola dalam melakukan fungsi pelayanan terhadap masyarakat. Hasil analisa SWOT yang dilakukan peneliti terhadap kurangnya tanggung jawab badan pengelola dalam pelayanan air bersih masyarakat memiliki bobot $12,82 \%$ yang merupakan bentuk ancaman terhadap keberlangsungan Program PAMSIMAS.

- Program PAMSIMAS merupakan kebijakan nasional dalam pembangunan air minum yang menggariskan bahwa tujuan pembangunan air minum dan penyehatan lingkungan adalah terwujudnya kesejahteraan masyarakat melalui pengelolaan pelayanan air minum. Hasil analisa SWOT terhadap faktor eksternal kurangnya dukungan pemda merupakan bentuk ancaman terhadap Program PAMSIMAS meiliki bobot $12.82 \%$.

- Monitoring dan evaluasi terhadap kinerja badan pengelola dan Lembaga Keswadayaan Masyarakat merupakan bagian tugas yang dilakukan untuk mencapai tujuan Program PAMSIMAS. Hasil analisa SWOT terhadap rendahnya umpan balik dan tindak lanjut hasil temuan dilapangan melalui monitoring menjadikan ancaman bagi badan pengelolan dalam Program PAMSIMAS yang memiliki bobot $17,95 \%$.

- Keikutsertaan masyarakat dalam pengelolaan air bersih bersama sama dengan badan pengelola di Desa Jejeg Kabupaten Tegal masih sangat rendah. Kurangnya keikutsertaan masyarakat dalam pengelolaan air bersih menjadi ancaman bagi badan pengelola dalam mewujudkan tujuan Program PAMSIMAS. Hasil analisa SWOT ancaman ini memiliki bobot $17.95 \%$. 
Tabel 4. Matrik Urgensi Faktor Kondisi Eksternal

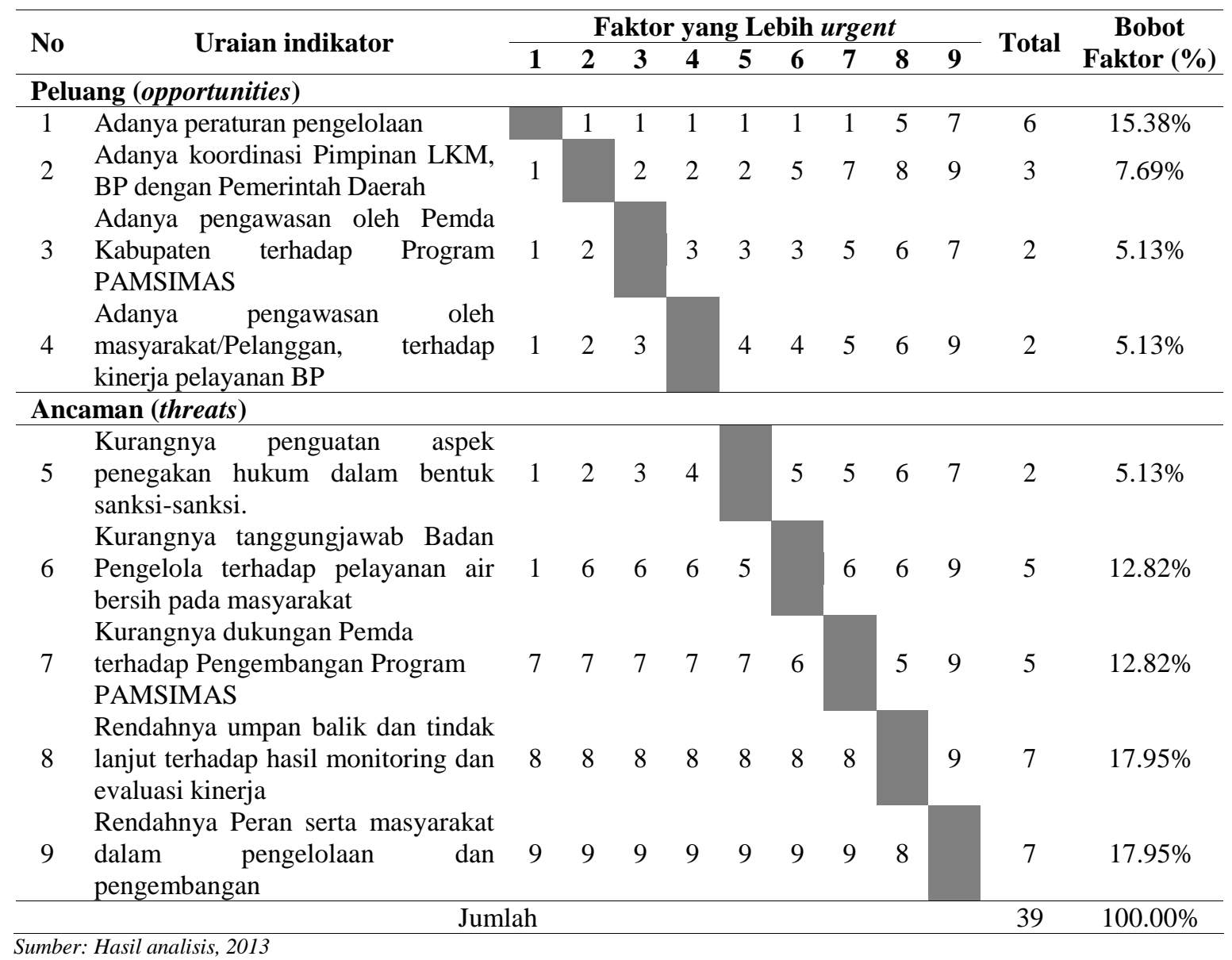

Kekuatan organisasi dan penyusunan strategi badan pengelola Desa Jejeg.

Berdasarkan posisi kuadran strategi pengembangan kapasitas pelayanan air bersih dan matrikulasi analisis SWOT, strategi agresif atau disebut juga strategi pengembangan diimplementasikan guna mengembangkan kapasitas pelayanan air bersih Program PAMSIMAS. Adapun rumusan strategi pengembangan kapasitas pelayanan air bersih di Desa Jejeg adalah sebagai berikut:

1. Memanfaatkan potensi sumber air baku yang ada yang secara kuantitas maupun kualitas baik untuk digunakan sebagai sumber air baku bagi masyarakat Desa Jejeg.

2. Melakukan pengamanan dan penjagaan air baku untuk menjaga kuantitas dan kualitasnya karena Desa Jejeg pengambilan sumber air baku pada sumber mata air di kawasan lindung.

3. Menetapkan, menata dan menjaga suatu lahan/kawasan sesuai dengan fungsinya.

4. Untuk LKM dan Badan Pengelola sebagai berikut:

a. melakukan peningkatan kualitas pelayanan; b. memanfaatkan kelebihan kapasitas produksi yang ada dengan cara mengoptimalkan wilayah pelayanan yang belum terlayani sambungan tetapi sudah tersedia jaringan perpipaannya;

c. mengembangkan cakupan pelayanan dengan melihat dari kapasitas sumber air dan masih mencukupi untuk memenuhi kebutuhan air bersih masyarakat di Desa Jejeg;

d. melakukan peningkatan dan pemeliharaan jaringan pipa. Agar tidak terjadinya kebocoran dalam pendistribusian air bersih, hal ini menyebabkan terjadi permasalahan dalam penyediaan air bersih Program PAMSIMAS;

e. peningkatan sarana dan prasarana penunjang.

Dari hasil Evalusi Faktor Eksternal dan Internal dapat diketahui jumlah Total Nilai Bobot (TNB) seluruh faktor, yaitu sebagai berikut: 1 . Total nilai bobot terhadap strength TNB-S sebesar 5,85; 2. Total nilai bobot terhadap weaknesses TNB-S sebesar 1,33; 3. Total nilai bobot terhadap opportunities TNB-O sebesar 2,36 dan 4. Total nilai bobot terhadap threats TNB-Tsebesar 5,35. 


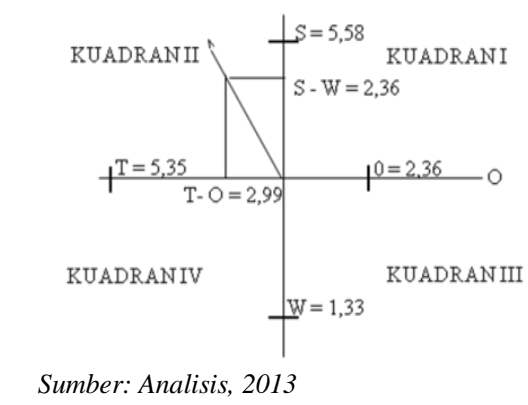

Gambar 1. Posisi kekuatan organisasi

Analisis pengembangan potensial pelayanan air bersih

Pengembangan potensial pada Program PAMSIMAS Desa Jejeg dapat dilakukan dengan memperhatikan tujuan Program PAMASIMAS secara keseluruhan dan membandingkannya dengan kondisi pelayanan saat ini ditambah dengan arahan pengembangan pelayanan dan penyediaan air bersih Desa Jejeg.

Untuk mengetahui pengembangan potensial pelayanan air bersih pada suatu wilayah maka salah satu cara yang dapat dilakukan adalah dengan metode Superimpose peta, adapun petapeta yang akan dipakai untuk mendapatkan pengembangan potensial suatu wilayah yaitu: Peta wilayah pelayanan air bersih Program PAMSIMAS Desa Jejeg. Wilayah pelayanan air bersih Program PAMSIMAS Desa Jejeg sampai saat ini belum mencapai seluruh bagian Desa Jejeg dan tekanan air yang diterima oleh pelanggan pada lokasi-lokasi tertentu tekanannya masih kecil, hal ini karena terbatasnya tekanan yang ada untuk melayani daerah ujung-ujung pipa distribusi. Peta ini memberikan gambaran wilayah yang terlayani oleh Program PAMSIMAS dan akan digunakan sebagai pembanding utama dalam pengembangan potensial pelayanan air bersih.

Matriks SWOT dapat disusun suatu formulasi strategi dengan mengintegrasikan faktor-faktor internal dan eksternal berdasarkan faktor kunci sukses, selanjutnya dimasukkan kedalam Tabel 5.

Tabel 5. Formulasi strategi SWOT

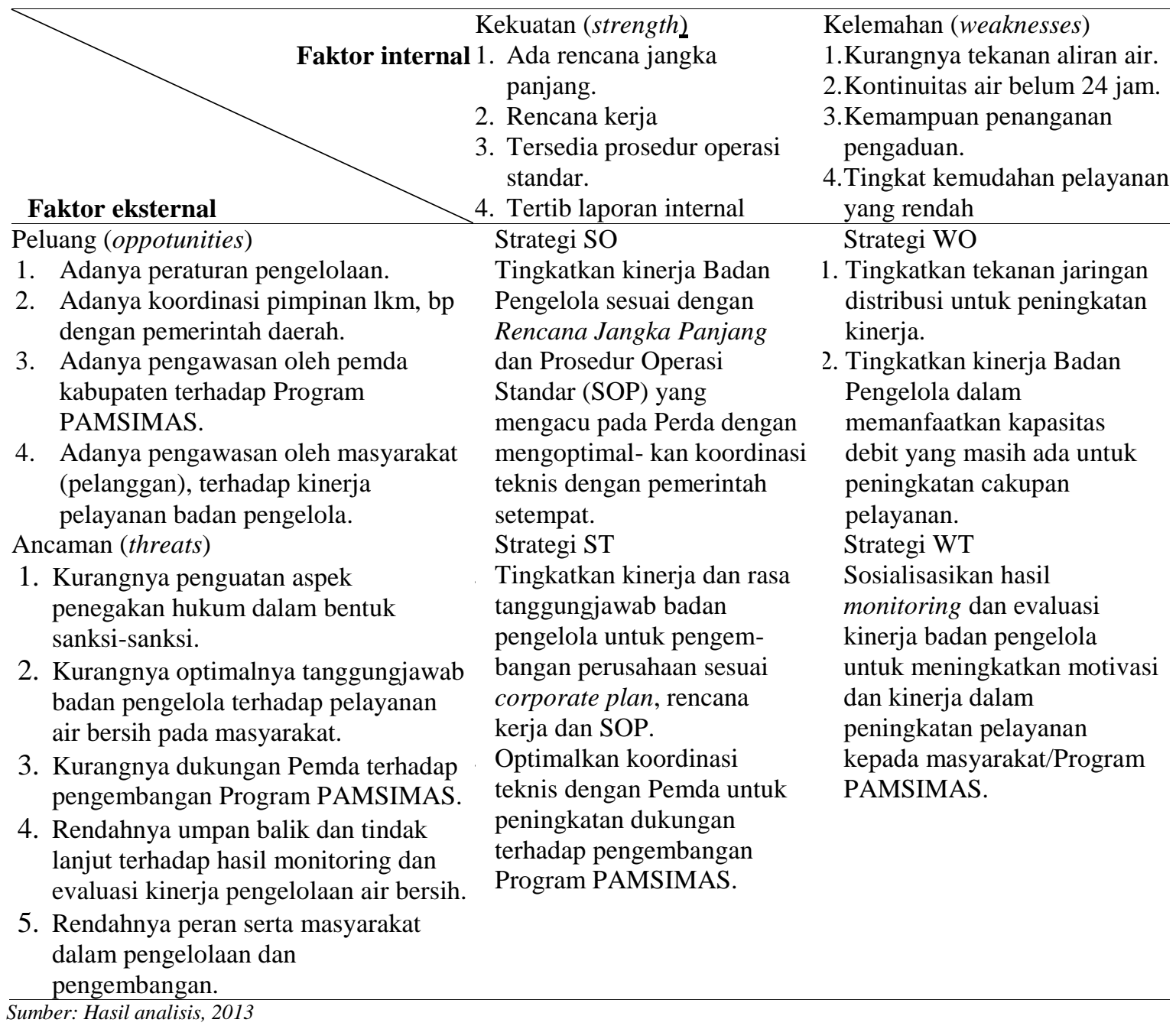




\section{Strategi peningkatan kapasitas pelayanan air bersih Desa Jejeg}

Berdasarkan strategi pengembangan kapasitas pelayanan air bersih dan pengembangan potensial, maka strategi peningkatan kapasitas pelayanan air bersih Program PAMSIMAS di Desa Jejeg adalah sebagai berikut:

a. Memanfaatkan sumber airbaku yang ada yang berasal dari sumber mata air lainnya, yang secara kualitas maupun kuantitas tergolong cukup baik untuk pemenuhan kebutuhan air bersih Desa Jejeg dengan menggunakan system distribusi air bersih yang dikelola oleh pihak Kelompok Pengguna air.

b. Melakukan pengamanan dan peningkatan kualitas serta kuantitas sumber mata air yang dijadikan sebagai sumber air baku. Peningkatan kualitas dan kuantitas sumber air baku dapat dilakukan dengan cara pelestarian kawasan lindung secara terpadu guna menjaga siklus air.

Melakukan peningkatan cakupan pelayanan air bersih Program PAMSIMAS di Desa Jejeg.

\section{Kesimpulan}

\section{Hasil analisis tingkat kepuasan masyarakat}

Dari hasil analisis berdasarkan skala likert, diperoleh tingkat kepuasan masyarakat terhadap pelayanan air bersih Program PAMSIMAS di Kabupaten Brebes sebesar 3,60 dan kepuasan masyarakat terhadap pelayanan air bersih di Kabupaten Tegal sebesar 3,79 Nilai tingkat kepuasan pelanggan ini, termasuk kategori kepuasan tinggi $(3,00-4,00)$.

Walaupun hasil analisis tersebut memperlihatkan kategori tingkat kepuasan tinggi, namun dalam mensikapi pelayanan dan penyediaan air bersih Program PAMSIMAS di kedua kabupaten tersebut masyarakat dalam kondisi belum secara maksimal terlayani, artinya perlu adanya peningkatan kualitas pelayanan dari beberapa aspek teknik operasinal dan aspek administrasi/manajemen yang masih menjadi kendala, terutama dari kontinuitas air bersih dan kondisi kemampuan penanganan pengaduan oleh badan pengelola untuk desa yang ada di Kabupaten Tegal.

\section{Penilaian kinerja pelayanan air bersih Program PAMSIMAS di Kabupaten Tegal dan Brebes}

Penilaian kinerja pelayanan air bersih ditinjau berdasarkan acuan normatif, Kepmendagri No. 47 Tahun1999 yaitu dari aspek teknik operasional dan aspek administrasi, diperoleh hasil akhir penilaian kinerja sebesar 64,43Sesuai pasal 3 Kepmendagri No. 47 Tahun 1999 terhadap kategori kinerja dan tingkat keberhasilan Pelayanan air bersih dengan nilai skor > 45 - 60 maka Program PAMSIMAS di Kabupaten Brebes Kategori kinerja baik, artinya mencapai kinerja pelayanan yang di harapkan. Dan untuk Kabupaten Tegal penilaian kinerja sebesar 64,44 kategori baik dengan nilai skor > 60. Dari hasil analisis ini, Program PAMSIMAS di Kabupaten Tegal dan Brebes di indikasikan sebagai program penyediaan dan pengelolaan air bersih yang cukup memenuhi pada tingkat kinerja pelayanan yang diharapkan.

\section{Analisis SWOT}

Dalam upaya Badan Pengelola dan LKM mengoptimalkan kinerja pelayanannya, maka diperlukan adanya target-target serta strategi pada aspek teknik operasional dan administrasi/ manajemen sesuai dengan tujuan Program PAMSIMAS yang telah dicanangkan.

Berdasarkan hasil analisis SWOT (Strength, Weaknesses, Opportunities dan Threats), kekuatan kinerja Badan Pengelola Kabupaten Tegal dan Brebes menunjukkan posisi pada Kuadran I yang dipengaruhi oleh strength (kekuatan) dan threat (ancaman).

\section{Saran}

Untuk meningkatkan tingkat kepuasan masyarakat, disarankan Badan Pengelola Program PAMSIMAS di Kabupaten Tegal dan Kabupaten Brebes untuk melakukan peningkatan kinerja pelayanannya, antara lain berupa:

1. Peningkatan kapasitas sumber daya manusia dalam hubungannya dengan pelayanan akan pemenuhan kebutuhan air bersih melalui Program PAMSIMAS.

2. Meningkatkan pengawasan secara berkala dalam menjaga dan meningkatkan kontinuitas air bersih dalam pemenuhan kebutuhan air bersih bagi masyarakat yang akses air bersihnya rendah.

3. Peningkatkan kemudahan pelayanan kepada masyarakat dapat diwujudkan dalam peningkatan kapasitas badan pengelola dalam menyediakan pelayanan pengaduan terhadap keluhan masyarakat dalam melayanai kebutuhan air bersih. 


\section{Daftar Pustaka}

Alan Restu Jaya, Suharyanto, 2004. Analisis Jaringan Air Bersih PDAM di Kampung Pesaten Kelurahan Rejomulyo Semarang, Alumnus Magister Teknik Sipil Universitas Diponegoro Semarang.

Arikunto, Suharsimi, 1997. Prosedur Penelitian, Rineka Cipta, Jakarta.

Badan Perencanaan Pembangunan Nasional, 2007. Evaluasi Independen Program WSSLIC dan Pamsimas.

Chatib, Benny, 1996. Sistem Penyediaan Air Bersih, Diklat Tenaga Teknik PAM., LPM-ITB, Bandung.

Departemen Dalam Negeri RI, 1999. Keputusan Menteri Dalam Negeri No. 47 Tahun 1999 tentang Pedoman Penilaian Kinerja PDAM.

Departemen Kesehatan Republik Indonesia, 2002. Keputusan Menteri Kesehatan No. 907/MENKES/SK/VII/2002 tentang Syarat Syarat dan Pengawasan Kualitas Air Minum.

Gasperzs, V., 1995. Teknik Analisis dalam Penelitian Percobaan, Jilid dua, Tarsito, Bandung.

Grigg, Neil S., 1996. Water Resources Management, Principles, Regulation, and Cases, Mc Graw Hill, New York.

Jayadinata, Johara T., 1999. Tata Guna Tanah dalam Perencanaan Pedesaan, Perkotaan, dan Wilayah, ITB, Bandung.

Ketentuan Umum Permenkes No. 416/Menkes/PER/IX/1990 tentang Persyaratan Air Bersih.

Kodoatie, 2002. Pengelolaan Sumber Daya Air dalam Era Otonomi Daerah, Pustaka Pelajar, Jogyakarta.
Kodoatie, Robert J., 2003. Pengantar Manajemen Infrastruktur, Pustaka Pelajar, Yogyakarta.

Lincoln, Yvonna S., dan Egon G., Guba, 1985. Naturalistic Inquiry, Sage Publication, Baverly Hills.

Nasution, S., 2000. Penelitian Ilmiah, Penerbit Bumi Aksara, Jakarta.

Neuman, M., Lawrence, 2003. Social Research Methods (Qualitatif and Quantitative Aproaches) Fifth Edition, USA.

Nurandani Hardyanti \& Nurmeta Diana Fitri, 2006. Studi Evaluasi Pengelolaan Air Bersih untuk Kebutuhan Domestik dan Non Domestik (Studi Kasus Perusahaan Tekstil Bawen Kabupaten Kabupaten Semarang, Faklutas Teknik, Universitas Diponegoro, Semarang.

Patton, Michael Quinn, 2009. Metode Evaluasi Kualitatif, Pustaka Pelajar, Yogyakarta.

Peraturan Pemerintah Republik Indonesia No. 16 Tahun 2005 tentang Pengembangan Sistem Penyediaan Air Minum.

Rondinelli, Dennis A., 1990. Decentralizing Urban Development Programme, USAID.

Setiyo P., Sigit, Sistem Unbundling pada Pengelolaan Air Bersih di Tingkat Kota maupun Kabupaten, Universitas Gunadarma, Depok.

Silalahi, Ulber, 2009. Metode Penelitian Sosial, PT. Refika Aditama, Bandung.

Yin, R., 1996. Studi Kasus: Desain dan Metode, Radja Grafindo Persada, Jakarta. 